\title{
ESTIMATION AND SELECTION OF PARENTAL FORMS FOR BREEDING KAZAKHSTAN SALT TOLERANT RICE VARIETIES
}

\section{D.S. BATAYEVA ${ }^{1}$, B.N. USENBEKOV ${ }^{2}$, A.B. RYSBEKOVA ${ }^{3}$, Zh.M. MUKHINA ${ }^{4}$, D.T. KAZKEYEV5, Ye.A. ZHANBYRBAYEV 5 , I.A. SARTBAYEVA ${ }^{2}$, S.V. GARKUSHA ${ }^{4}$, S.A. VOLKOVA 6}

\author{
${ }^{1}$ Kazakh State Women's Pedagogical University, 99, Aiteke Bi str., Almaty, Republic of Kazakhstan 050000, e-mail \\ dariga_2382@mail.ru; \\ ${ }^{2}$ Institute of Plant Biology and Biotechnology, 45, Timiryazev str., Almaty, Republic of Kazakhstan 050040, e-mail \\ gen_dauren@mail.ru; \\ ${ }^{3}$ Saken Seifullin Kazakh Agrotechnical University, 62, Pobeda str., Astana, Republic of Kazakhstan 010000, e-mail \\ aiman_rb@mail.ru; \\ ${ }^{4}$ All-Russiam Rice Research Institute, Federal Agency of Scientific Organizations, 3, Belozernii, Krasnodar, Russia \\ 350921, e-mail agroplazma@gmail.com (corresponding author); \\ ${ }^{5}$ Kazakh National Agrarian University, 8, Abay av., Almaty, Republic of Kazakhstan 050010, e-mail el- \\ dos_83@mail.ru; \\ ${ }^{6}$ Kuban State Agrarian University, 13, ul. Kalinina, Krasnodar, Russia 350044, e-mail mail@kubsau.ru \\ ORCID: \\ Batayeva D.S. orcid.org/0000-0002-2577-1894 \\ Usenbekov B.N. orcid.org/0000-0002-0951-1275 \\ Rysbekova A.B. orcid.org/0000-0001-5253-3464 \\ Mukhina Zh.M. orcid.org/0000-0003-3557-1615 \\ Zhanbyrbayev Ye.A. orcid.org/0000-0002-4076-8108 \\ Sartbayeva I.A. orcid.org/0000-0001-7090-9373 \\ Garkusha S.V. orcid.org/0000-0002-3974-9153 \\ Volkova S.A. orcid.org/0000-0003-1617-0592
}

Kazkeyev D.T. orcid.org/0000-0003-3597-7594

The authors declare no conflict of interests

Received October 4, 2016

\section{Abstract}

About $25 \%$ of the entire land surface is represented by saline soils, and up to $90 \%$ of the total irrigated area - in some regions of Central Asia and the Caucasus, Ukraine and Kazakhstan. Rice-growing region of the Republic of Kazakhstan is also located in the area with high salinity. A challenge for rice growing in Kazakhstan is deteriorating humus and reclamation of soil, rise in soil secondary salinity and degradation. In Kyzylorda region, pollution of surface (up to 3-5 g/l) and ground water (up to 6-7 g/l) by salt residues reaches a critical point. The dominating sulfatechloride-sodium type of salinity is especially toxic for crops. Akdalinski and Karatal zones of irrigation in the Almaty region are also located within the provinces of sulfate-soda and boric biogeochemical soil salinity. According the data of Kazakh Rice Research Institute, in recent years the rice yields and yield quality have sharply decreased - from 50 to 35-48 centners per hectare, and from 65 to $45-50 \%$ of the groats output, respectively. In this regard, the rice breeding for salt tolerance is the most important to ensure food security in Kazakhstan. The objective of our study was the evaluation and selection a promising starting material of rice resistant to different types of salinity. To this end, we studied the rice (Oryza sativa L.) varieties, collection samples and their hybrid combinations of different generations derived from Russia, Kazakhstan and Philippine (34 genotypes in total). For the initial assessment at the seedling stage we used the laboratory screening for tolerance to various types of salinity, i.e. chloride, sulphate and carbonate. Saline stress negatively affected seedling growth and total weight in the studied samples. It was revealed that the carbonate type of salinity is the most toxic for rice plants; the chloride and sulfate types were less adverse. The hybrid collection sample $F_{2}$ Khankai $429 \times 4-09$ and as well as varieties Marzhan and Madina accumulated the highest percentage of biomass compared to the control at the salinity of all three types. Therefore, these genotypes are valuable in selection for salt tolerance. Molecular screening of chromosomal DNA regions linked to quantitative trait loci of salt tolerance (Saltol QTL) by PCR with microsatellite markers closely linked to the target chromosomal regions, RM 493 and AP 3206, showed RM 493 to produce polymorphism which allowed to distinguish the studied genotypes contrasting in salt tolerance. Thus RM 493 is informative to rank the rice genetic plasma by salt tolerance.

Keywords: Oryza sativa L., rice, chloride salinity, sulfate salinization, carbonate salinity, molecular screening for salt tolerance, SSR markers, selection

About 950 million hectares of agricultural lands in the world are saline, 
and 77 million hectares are irrigated by saline water. According to forecasts, salinity will affect over $50 \%$ of cultivated areas by 2050 [1]. In Russia, saline soils occupy 15 million hectares, including 196.4 thous. ha in Krasnodar Krai, of which 76.4 thous. ha are irrigated areas, and over $85 \%$ of them are in rice irrigation systems.

Soil salinity of more than $0.35 \%$ kills rice plants. One of serious challenges for rice growing in the Republic of Kazakhstan is deteriorating humus and reclamation conditions of soil, rise in soil secondary salinity and degradation. Currently, the area of saline and alkaline soils is 111.6 million hectares, or $41.0 \%$ of the entire territory of the republic. In Kyzylorda region, pollution of surface (up to 3-5 g/l) and ground water (up to 6-7 g/l) by salt residues reaches a critical point. In the most $(30 \%)$ irrigated rice-planting areas, groundwater salinity reaches 5-10 g/l. As a consequence, the crop yields there decrease by 20 $50 \%$ [2]. By chemical composition, sulfate-chloride-sodium type of salinity dominates there, which is especially toxic for agricultural plants. Akdala and Karatal zones of irrigation in Almaty region (another important rice-planting region of Kazakhstan) are also located within the provinces of sulfate-soda and boric biogeochemical soil salinity. Excess amounts of water-soluble salts in soil cause thinning of seedlings, retards plant growth and development. According to the data of Kazakh Rice Research Institute, in recent years it has resulted in sharp decrease in rice yields (from 50 to $35-48 \mathrm{c} / \mathrm{ha}$ ) and rice quality (groats output has reduced from 65 to $45-50 \%$ ) [3].

Nowadays, the leading rice varieties cultivated in Kazakhstan cannot meet the increased needs of the processing and food industry because of expansion of re-saline soil areas. The yield decrease in saline soils may be overcome by soil reclamation and increasing rice tolerance to salinity. Rice selection for the leading rice-planting regions of the Republic of Kazakhstan (Kyzylorda and Almaty regions) shall be aimed at creation of varieties tolerant to salinity, resistant to diseases and pests, having high groats productivity and quality. Introducing the salt tolerant varieties into agricultural practices is a cost-effective method and a primary objective for the modern rice growing in Kazakhstan.

The ability of plants to survive and complete a reproduction cycle in conditions where there are salt concentrations unfavorable for the most of other species is commonly called salt tolerance. According to B.P. Strogonov, there are biological and agronomical types of salt tolerance [4, 5]. Salt tolerance is a polygenic trait manifested in a number of various physiological responses affecting plant metabolism and occurring at different levels [6]. There are direct and indirect methods for estimation of plant salt tolerance which involve the assessment of yields and productivity, seed germination rate, cell plasmolysis intensity, chlorophyll bleaching in leaves of seedlings placed into saline solutions [7].

It is expedient to estimate salt tolerance by the agricultural resistance, i.e. by plant ability to keep yields typical for nonsaline conditions when grown in saline soil. Resistance to soil salinity varies in vegetation stages; there are two critical phases in the ontogenesis of rice plants: during germination-formation of seedlings and blooming [8-11].

In this work, we for the first time have conducted screening of the Kazakhstan rice lines for salt tolerance at the early stage of vegetation and their molecular analysis using microsatellite markers.

The objective of our study was to evaluate and select a promising starting material for breeding rice for tolerance to different types of salinity.

Technique. The following rice (Oryza sativa L.) varieties and collection samples (including their hybrid combinations of different generations) were the subjects of the study: Liman, Regul, Dariy 23, Sonata, VNIIR10173, Slavyanets, 
Khankai 429, Fisht, Yantar, Rapan, Kuban 3, Atlant, Serpantin, Kurchanka varieties and collection samples 4-09 and 49-09 derived from Russia; Madina, Analog II, Bakanassky, Marzhan varieties, collection sample 34-09, and $F_{2}$ Sonata $\times$ Liman, $F_{2}$ Regul $\times$ Kurchanka, $F_{2}$ Dariy $23 \times$ collection sample $49-09, F_{2}$ Khankai $429 \times$ collection sample 4-09, F 2 Marzhan $\times$ Kurchanka, F $F_{2}$ Bakanassky $\times$ Analog II, $F_{2}$ Dariy $23 \times$ Analog II, $F_{2}$ Kuban $3 \times$ collection sample $34-$ 09, $\mathrm{F}_{2}$ Khankai $429 \times$ Kurchanka hybrid lines derived from Kazakhstan; FL 478 HB 9093, BINA dhan 8 HB 9106, BRRI dhan 47 HB 9114 varieties derived from Philippines. The varieties of Marzhan (Kazakh salt tolerant standard), Kurchanka (Russian salt tolerant standard), FL 478 HB9093, BINA dhan 8 HB9106, BRRI dhan 47 HB9114 (salt tolerant samples obtained from the International Rice Research Institute - IRRI, the Philippines) were used as a positive control in all experiments.

Phenological observations were made by P.S. Yerygin [12].

The varieties, collection samples and hybrid lines were screened for salt tolerance at the germination stage under laboratory conditions according to the procedure of All-Russian Rice Research Institute [13]. For that, the seeds were sprouted in a thermostat at $29{ }^{\circ} \mathrm{C}$ for 4 days under salinity stress $(0.75 \% \mathrm{NaCl}$, $0.75 \% \mathrm{Na}_{2} \mathrm{SO}_{4}, 0.075 \% \mathrm{Na}_{2} \mathrm{CO}_{3}$ ) (in 3 replicates). On day 5, 20 typical germs of each sample were taken and weighted to $0.01 \mathrm{~g}$.

Molecular screening of chromosomal DNA regions linked to QTL (quantitative trait loci) of salt tolerance (Saltol QTL) was carried out by PCR analysis in $\mathrm{F}_{3}$ and $\mathrm{F}_{4}$ hybrid combinations. DNA was extracted by the CTAB method using 7-day old non-chlorophyllic seedlings [14]. Microsatellite markers closely linked to the target chromosomal regions, RM 493 and AP 3206, were applied [15]. The PCR was conducted using 40-50 ng of DNA in a final volume of $25 \mu \mathrm{l}$. The reaction mixture was composed of $0.05 \mathrm{mM}$ of dNTPs, $0.3 \mathrm{mM}$ of

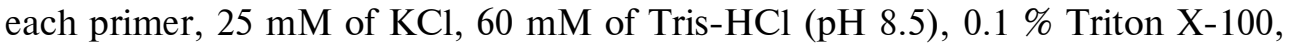
$10 \mathrm{mM}$ of 2-mercapto-ethanol, $1.5 \mathrm{mM}$ of $\mathrm{MgCl}_{2}, 1$ unit of Taq-polymerase (New England Biolabs, Inc., USA). DNA amplification was made as follows: initial denaturation for $4 \mathrm{~min}$ at $94{ }^{\circ} \mathrm{C}$; denaturation for $1 \mathrm{~min}$ at $94{ }^{\circ} \mathrm{C}$, annealing of primers for $1 \mathrm{~min}$ at $55^{\circ} \mathrm{C}$, elongation for $1 \mathrm{~min}$ at $72{ }^{\circ} \mathrm{C}$ (30 cycles); last cycle of synthesis for $5 \mathrm{~min}$ at $72{ }^{\circ} \mathrm{C}$. Primer pairs for the markers concerned were synthesized by Sintol (Moscow). Nucleotide sequences of primer pairs for RM493 were TAGCTCCAACAGGATCGACC $\left(5^{\prime} \rightarrow 3^{\prime}\right)$, GTACGTAAACGCGGAAGGTG $\left(5^{\prime} \rightarrow 3^{\prime}\right)$; and for AP3206 were GGAGGAGGAGAGGAAGAAG $\left(5^{\prime} \rightarrow 3^{\prime}\right)$, GCAAGAATTAATCCATGTGAAAGA $\left(5^{\prime} \rightarrow 3^{\prime}\right)$. The PCR was carried out in a Tertsik DNA amplifier (NPO DNA Technology, Russia). Polyacrylamide gel $(8 \%)$ based on $1 \times$ TBE (Tris- $\mathrm{HCl}-0.09 \mathrm{M}$, boric acid $-0.09 \mathrm{M}$, EDTA $-2 \mathrm{mM}$, pH 8.2) was used for electrophoretic separation of the PCR products. Visualisation was performed under the UV-light after gels had been colored by ethydium bromide.

The data obtained were processed in Microsoft Excel. The table presents arithmetical mean values $(M)$ and errors of mean $( \pm m)$.

Results. The salinity stress negatively affected the gain in total biomass of seedlings in the samples studied (see the Table). The maximum (as a percentage compared to the control) gain in biomass in the conditions of chloride salinity was observed for the varieties derived from Kazakhstan, Bakanassky and Marzhan; medium vales - for the varieties derived from Russia, Rapan, Yantar, Fisht, Sonata and Khankai 429. The minimum gain in the total biomass was noted in IRRI varieties: BINA dhan 8HB9106, FL 478 HB9093, BRRI dhan 47 HB9114, although they were considered to be standards for salt tolerance. Probably, salt tolerance in these samples is expressed at later stages of ontogenesis. 
Screening of rice (Oryza sativa L.) samples by the total biomass of seedlings compared to the control (\%) at different types of salinity (laboratory experiment, $M \pm m)$

\begin{tabular}{|c|c|c|c|}
\hline \multirow[b]{2}{*}{ Variety, sample, hybrid } & \multicolumn{3}{|c|}{ Salinity } \\
\hline & $\begin{array}{l}\text { chloride } \\
(0.75 \%)\end{array}$ & $\begin{array}{l}\text { sulfate } \\
(0.75 \%)\end{array}$ & $\begin{array}{l}\text { carbonate } \\
(0.075 \%)\end{array}$ \\
\hline BINA dhan 8 HB9106 & $45.45 \pm 2.73$ & $87.61 \pm 16.15$ & $61.50 \pm 10.45$ \\
\hline BRRI dhan 47 HB9114 & $46.19 \pm 4.89$ & $87.01 \pm 14.19$ & $74.43 \pm 8.15$ \\
\hline FL 478 HB9093 & $47.75 \pm 4.86$ & $79.47 \pm 5.77$ & $61.97 \pm 6.66$ \\
\hline Akdala & $74.98 \pm 8.25$ & $66.31 \pm 6.22$ & $59.65 \pm 6.46$ \\
\hline Analog II & $73.37 \pm 6.01$ & $97.02 \pm 19.46$ & $61.78 \pm 8.39$ \\
\hline Atlant & $75.26 \pm 4.91$ & $75.36 \pm 11.62$ & $66.90 \pm 10.71$ \\
\hline Bakanassky & $81.97 \pm 16.42$ & $65.39 \pm 8.75$ & $75.30 \pm 15.28$ \\
\hline VNIIR10173 & $73.24 \pm 9.69$ & $69.71 \pm 8.85$ & $63.00 \pm 32.50$ \\
\hline Dariy 23 & $71.72 \pm 12.26$ & $82.33 \pm 13.51$ & $62.10 \pm 5.61$ \\
\hline Collection sample $34-09$ & $75.86 \pm 6.33$ & $67.25 \pm 7.94$ & $73.68 \pm 5.76$ \\
\hline Collection sample 4-09 & $61.93 \pm 4.31$ & $87.47 \pm 22.14$ & $54.80 \pm 9.58$ \\
\hline Collection sample 49-09 & $70.50 \pm 3.09$ & $71.11 \pm 5.56$ & $74.31 \pm 6.07$ \\
\hline Kuban 3 & $79.29 \pm 6.50$ & $82.67 \pm 14.44$ & $68.86 \pm 9.06$ \\
\hline Kurchanka & $69.79 \pm 4.59$ & $74.02 \pm 12.02$ & $67.16 \pm 4.46$ \\
\hline Liman & $65.03 \pm 8.19$ & $70.50 \pm 7.49$ & $45.11 \pm 5.37$ \\
\hline Madina & $85.64 \pm 5.02$ & $78.41 \pm 10.95$ & $74.29 \pm 7.11$ \\
\hline Marzhan & $80.90 \pm 15.55$ & $78.90 \pm 7.37$ & $76.04 \pm 6.65$ \\
\hline Rapan & $71.15 \pm 14.91$ & $69.10 \pm 20.49$ & $73.03 \pm 17.24$ \\
\hline Regul & $70.36 \pm 12.61$ & $98.36 \pm 10.36$ & $75.15 \pm 13.77$ \\
\hline Serpantin & $81.42 \pm 5.14$ & $79.67 \pm 8.15$ & $60.15 \pm 7.11$ \\
\hline Slavyanets & $80.77 \pm 11.44$ & $65.10 \pm 3.52$ & $58.44 \pm 8.88$ \\
\hline Sonata & $70.23 \pm 6.56$ & $79.50 \pm 7.02$ & $55.62 \pm 3.15$ \\
\hline Fisht & $77.40 \pm 8.23$ & $83.97 \pm 8.76$ & $72.83 \pm 3.84$ \\
\hline Khankai 429 & $66.13 \pm 6.17$ & $75.39 \pm 4.12$ & $58.25 \pm 6.59$ \\
\hline Yantar & $72.97 \pm 12.66$ & $78.07 \pm 16.28$ & $57.29 \pm 4.06$ \\
\hline $\mathrm{F}_{2}$ Bakanassky $\times$ Analog II & $78.01 \pm 8.05$ & $71.90 \pm 6.78$ & $70.23 \pm 10.10$ \\
\hline $\mathrm{F}_{2}$ Dariy $\times$ Analog II & $73.08 \pm 9.68$ & $74.00 \pm 6.78$ & $62.84 \pm 3.97$ \\
\hline$F_{2}$ Dariy $23 \times$ collection sample $49-09$ & $67.34 \pm 6.05$ & $81.03 \pm 8.43$ & $77.06 \pm 7.07$ \\
\hline$F_{2}$ Kuban $3 \times$ collection sample $34-09$ & $89.48 \pm 7.44$ & $71.73 \pm 7.04$ & $72.26 \pm 4.63$ \\
\hline $\mathrm{F}_{2}$ Marzhan $\times$ Kurchanka & $68.37 \pm 11.37$ & $71.37 \pm 6.41$ & $67.76 \pm 10.91$ \\
\hline$F_{2}$ Regul $\times$ Kurchanka & $70.63 \pm 7.46$ & $58.79 \pm 5.36$ & $69.03 \pm 4.33$ \\
\hline $\mathrm{F}_{2}$ Sonata $\times$ Liman & $69.78 \pm 7.75$ & $77.56 \pm 6.05$ & $69.64 \pm 8.21$ \\
\hline$F_{2}$ Khankai $429 \times$ Kurchanka & $80.56 \pm 10.36$ & $72.60 \pm 6.25$ & $67.88 \pm 7.63$ \\
\hline$F_{2}$ Khankai $429 \times$ collection sample $4-09$ & $70.71 \pm 6.69$ & $96.74 \pm 31.91$ & $80.04 \pm 4.73$ \\
\hline
\end{tabular}

By their tolerance to sulfate salinity, the tested genotypes were divided into three groups: high tolerance genotypes (76-100\%), medium tolerance genotypes (70-75\%), and low tolerance genotypes (0-69\%). The high tolerance was observed in the varieties derived from Kazakhstan, Marzhan (78 \%) and Madina (77\%); in varieties obtained from the IRRI, FL 478 HB 9093 (79 \%), BRRI dhan 47 HB 9114 (85\%), and BINA dhan 8 HB 9106 (87\%); and also in Russian varieties, Kuban $3(82 \%)$, Fisht $(82 \%)$, Sonata (80\%), Atlant (93\%), Regul (97\%), Dariy $23 \times$ collection sample 49-09 $(80 \%)$, Khankai $429 \times$ collection sample 4-09 (91\%). The low tolerance to this selective factor was noted for seedlings of varieties and hybrids Bakanassky, Rapan, Slavyanets, Akdala, VNIIR10173, $F_{2}$ Regul $\times$ Kurchanka, and collection sample 34-09.

For sodium carbonate salinity, more damaging impact on the absorption capacity of rice roots is characteristic as compared to the chloride and sulfate ones [16]. In our experiments, the varieties derived from All-Russian Rice Research Institute, i.e. Liman, Sonata, Yantar, Slavyanets, Khankai 429, VNIIR10173, and Serpantin, were the most sensitive to carbonate salinity. The maximum gain in biomass was characteristic of Marzhan, Regul, Madina, $\mathrm{F}_{2}$ Dariy $23 \times$ collection sample 49-09, and $F_{2}$ Khankai $429 \times$ collection sample 4-09.

There are various theories which explain the inhibition of plants in saline conditions. According to one of theories, the phenomenon is defined by osmotic influence of saline solutions, while the other one says that the plant growth and development are inhibited as a result of toxic effects of absorbed ions on physio- 
logical and biochemical processes [17]. In our experiments, carbonate salinity was the most toxic, while chloride and sulfate types of salinity were less adverse.
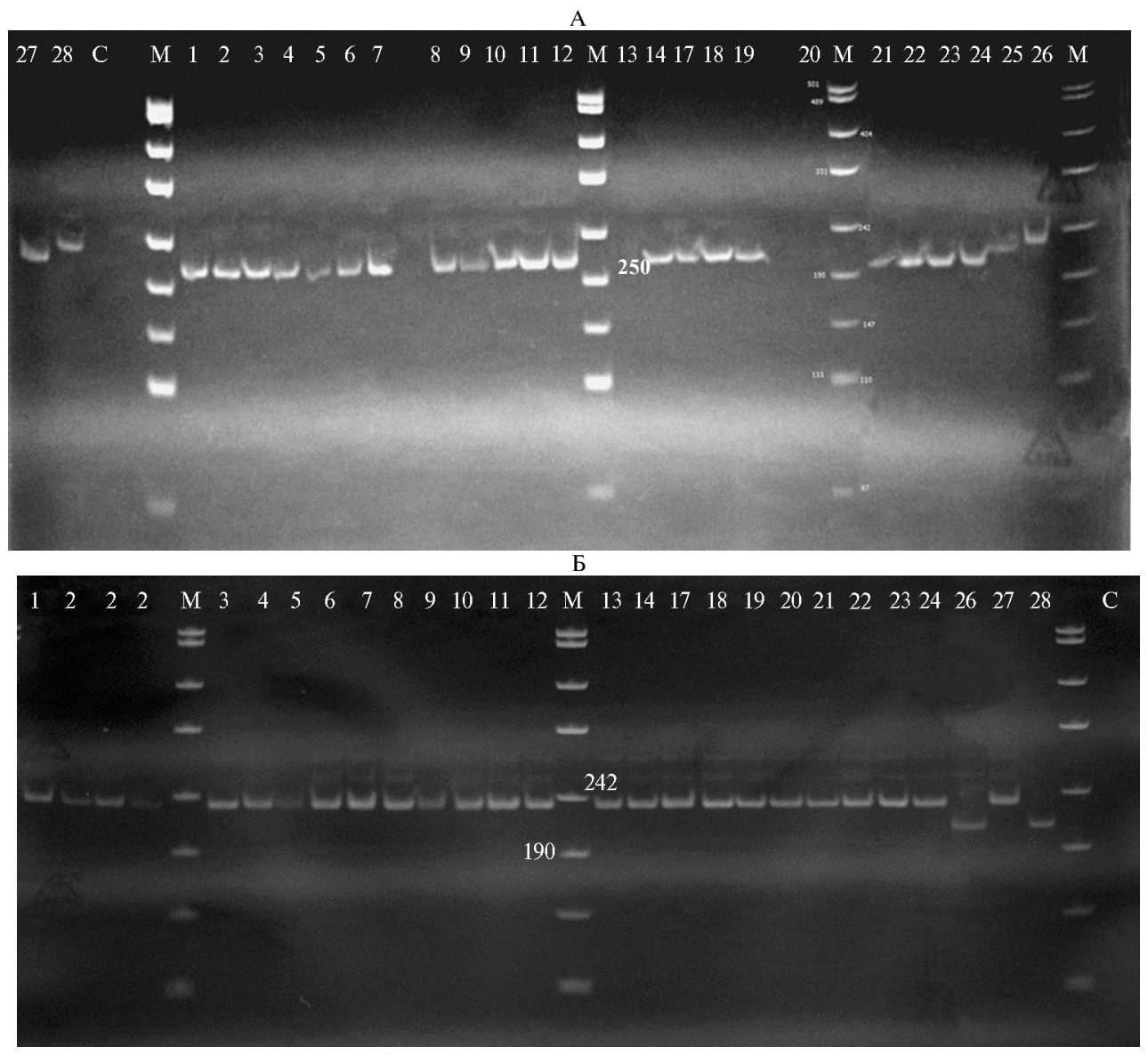

Microsatellite profiles in rice (Oryza sativa L.) samples derived from Russia, Kazakhstan and global selection for RM 493 (A) and AP3206 loci (B): 1 - Marzhan, 2 - Kurchanka, 3 - F 4 Marzhan $\times$ Kurchanka var. dichroa; $4-\mathrm{F}_{4}$ Marzhan $\times$ Kurchanka var. zeravschanica, $5-\mathrm{F}_{4}$ Marzhan $\times$ Kurchanka var. italica, $6-\mathrm{F}_{4}$ Marzhan $\times$ Kurchanka var. vulgaris, $7-$ Regul, $8-\mathrm{F}_{3}$ Regul $\times$ Kurchanka var. italica, $9-\mathrm{F}_{3}$ Regul $\times$ Kurchanka var. zeravschanica, $10-\mathrm{F}_{3}$ Regul $\times$ Kurchanka var. dichroa, $11-$ Sonata, $12-$ Liman, $13-\mathrm{F}_{4}$ Sonata $\times$ Liman var. italica, $14-\mathrm{F}_{4}$ Sonata $\times$ Liman var. nigroapiculata, $17-\mathrm{F}_{3}$ Kuban $3 \times$ collection sample 34-09 var. zeravschanica, $18-$ Khankai 429, $19-\mathrm{F}_{4}$ Khankai $429 \times$ Kurchanka var. dichroa, $20-$ Bakanassky, 21 - Analog II, $22-\mathrm{F}_{4}$ Bakanassky $\times$ Analog II var. nigroapiculata, $23-$ Dariy 23, $24-\mathrm{F}_{3}$ Dariy $23 \times$ Analog II var. italica, 25 - FL 478 HB9093, 26 - BINA dhan8 HB9106, 27 - BRRI dhan47 HB9114, 28 Madina, $\mathrm{C}-\operatorname{control}\left(\mathrm{H}_{2} \mathrm{O}\right)$; $\mathrm{M}$ - molecular mass marker (bp) 100 bp (Sintol, Moscow).

For the PCR analysis of DNA (see the Figure), we used microsatellite markers RM 493 and AP 3206 defined inside of Saltol region in chromosome 1. Comparison of microsatellite profiles in the samples tested allows for the conclusion about the presence of three alleles in RM 493 locus: the first one was found in BINA dhan8 HB9106 genotypes (salt tolerant standard, IRRI) and Madina variety derived from Kazakhstan; the second one - in FL 478 HB9093 and BRRI dhan 47 HB9114 genotypes (salt tolerant standards, IRRI); and the third one - in all other samples (see the Figure). It is notable that the latter also includes salt tolerant standards, Marzhan variety derived from Kazakhstan and Kurchanka variety derived from Russia. Salt tolerance of these rice genotypes of Russian and Kazakhstan origin was more likely defined by other QTL.

The use of AP 3206 made it possible to reveal polymorphism, but this 
microsatellite marker appeared to be less informative as compared to RM 493 (see the Figure). Profiles of PCR products were similar almost in all samples studied, except for two ones - BINA dhan8 HB9106 (path 26) and Madina (path 28), that provided evidence of existence of two salt tolerance alleles for AP 3206 locus.

Marker-assisted selection (MAS) widely used now [18], including for increase of salt tolerance in plants, has enabled to make great progress as compared to traditional methods [19-22]. It helps significantly cut time required for creation of new genotypes, assess the purity and identity of varieties, study the genetic diversity of modern varieties, define genes and quantitative trait loci (QTL), reveal markers closely linked to genes and QTL of target traits, monitor types of crossings and introgression of genes and QTL in different MAS patterns, and implement gene stacking [23, 24].

Salt tolerance in rice is controlled by several independent loci responsible for the trait formation at different stages of ontogenesis. The key loci, among others, are SKC1 and Saltol. Saltol belongs to QTL and has been defined in chromosome 1 of salt tolerant Pokkali rice [25, 26]. A technology of molecular genetic screening for salt tolerance enables to immediately select forms of plants having target genes and create varieties with predefined properties and without using challenges [27, 28]. According to literature data, introduction of Saltol QTL into highly productive varieties stabilizes the rice yields in saline soils [29]. Currently, we have already carried out hybridization among Bakanassky, Marzhan, Madina, Kuban 3 varieties and BINA dhan 8HB 9106, FL 478 HB 9093, BRRI dhan 47 HB 9114 salt tolerance donors for the purpose of Saltol QTL introgression into rice varieties grown in Kazakhstan (no data provided). The next stages in the selection pattern will be a series of backcrossings with Kazakh varieties as recipient forms and further testing of the obtained lines under field conditions, DNA identification of Saltol-loci in the lines and creating salt tolerant Kazakh rice varieties based on them.

It has been reported that polymorphic SSR markers linked to QTL of salt tolerance, such as RM 490, RM 1287, RM 10694, AP 3206, AP 3206f, RM 8094, RM 3412b, RM 10748, RM 493, RM 10793, SalT 1, RM 562, RM 7075, are the most promising in the molecular genetic analysis of target DNA regions [30]. In our studies, microsatellite marker RM 493 has appeared to be informative to rank the rice genetic plasma for the presence of Saltol locus of salt tolerance.

Thus, the studied rice genotypes of different origin have shown heterogeneity in tolerance to carbonate, chloride and sulfate types of salinity during screening at the seedling stage (the carbonate salinity appeared to be the most toxic). In the molecular genetic analysis of samples contrasting in salt tolerance, polymorphism has been revealed in one of the two microsatellite markers used, i.e. RM 493 defined inside of Saltol region. Three alleles of this microsatellite locus have been found in the genotypes under study; one of them is characteristic of the most genotypes studied, the second one has been identified in two varieties derived from the Philippines, and the last one has been found in one Philippine and one Kazakh varieties.

So, the screening of 34 genotypes of rice (varieties, collection samples derived from Russia, Kazakhstan and the Philippines, and their different hybrid combinations) has revealed the most promising salt tolerant varieties and hybrids which may be grown in saline soils as well as used as a starting material for breeding higher salt tolerant forms. Hybrid $F_{2}$ Khankai $429 \times$ collection sample 4-09 as well as Marzhan and Madina varieties gained the maximum percentage biomass in three types of salinity (chloride, sulfate and carbonate). Hence, these genotypes are of value as a starting material for breeding programs aimed at improving salt 
tolerance. To monitor the introgression of Saltol locus, polymorphic microsatellite marker RM 493 may be used, which appeared to be the most informative during the analysis of the genotypes contrasting in the studied trait.

\section{REFERENCES}

1. Tk a c he n k o Yu.A., D o s e e v O.A. Risovodstvo, 2007, 10: 59-66 (in Russ.).

2. B enduhn F., Renard P. A dynamic model of the Aral Sea water and salt balance. $J$. Marine Syst., 2004, 47: 35-50.

3. U mirzakov S.I. Materialy Mezhdunarodnoi nauchno-prakticheskoi konferentsii «Nauchnoinnovatsionnye osnovy razvitiya risovodstva $v$ Kazakhstane $i$ stranakh zarubezh'ya» [Proc. Int. Conf. «Science and innovations in rice breeding in Kazakhstan and abroad]. Kyzylorda, 2012: 17 (in Russ.).

4. C troga nov B.P., K ly she v L.K., A z i mov R.A. Problemy soleustoichivosti rastenii [Salt tolerance in plants]. Tashkent, 1989 (in Russ.).

5. Hosseini S.J., Tahm a s ebi S.Z., Pirdashti H. Screening of rice (Oryza sativa L.) genotypes for $\mathrm{NaCl}$ tolerance at early seedling stage. International Journal of Agronomy and Plant Production, 2012, 3(8): 274-283.

6. Abbas M.K., Ali A.S., H a s a n H.H., G hal R.H. Salt tolerance study of six cultivars of rice (Oryza sativa L.) during germination and early seedling growth. J. Agr. Sci., 2013, 5(1): 250-258 (doi: 10.5539/jas.v5n1p250).

7. Bhowmik S.K., Titov S., Is la m M.M., Siddika A., Sultana S., Shahidul $\mathrm{H}$ a qu e M.D. Phenotypic and genotypic screening of rice genotypes at seedling stage for salt tolerance. Afr. J. Biotechnol., 2009, 8(23): 6490-6494.

8. Beletskii Yu.D., S h e v y a k ov a N.I., K a r n a u k hova T.B. Plastidy $i$ adaptatsiya rastenii $k$ zasoleniyu [Plastids and plany adaptiveness to salinization]. Rostov-na-Donu, 1990 (in Russ.).

9. Tiwari S., Krishnamurthy S.L., Kumar V., Singh B., Rao A.R., Mithra A., $\mathrm{R}$ a i V., S ingh A.K., S ing h N.K. Mapping QTLs for salt tolerance in rice (Oryza sati$v a$ L.) by bulked segregant analysis of recombinant inbred lines using 50K SNP chip. PLoS ONE, 2016, 11(4): e0153610 (doi: 10.1371/journal.pone.0153610).

10. U d o v e $\mathrm{n}$ k o G.V. V sbornike: Metody otsenki ustoichivosti rastenii $k$ neblagopriyatnym faktoram sredy [Methods to assay plant tolerance to adverse factors]. Leningrad, 1976: 228-238 (in Russ.).

11. Akbar M., Yabuno T., $\mathrm{Nak}$ a o $\mathrm{S}$. Breeding for saline resistant varieties of rice. I. Variability for salt tolerance among some rice varieties. Jpn. J. Breed., 1977, 22: 277-284.

12. Erygi n P.S., K ras no o k N.P. Osnovy biologii risa [Fundamentals of rice biology]. Moscow, 1965: 15-33 (in Russ.).

13. Skazhennik M.A., Vorob'ev N.V., Dose eva O.A. Metody fiziologicheskikh issledovanii $v$ risovodstve [Methods in rice physiology]. Krasnodar, 2009: 23 (in Russ.).

14. Singh R.K., Gregorio G.B., Ali S., Arceta M., Moham madi R., Vis po N.A., A mas J., Thoms on M., Gaut a m R., B ra r D.S., I s ma il A. Molecular screening and diversity of salt tolerance in rice genotypes. FSC Brief No 9. Food Security Center, Germany, 2011.

15. Murray M.G., Thom p o n W.F. Rapid isolation of high molecular weight plant DNA. Nucleic Acids Res., 1980, 8(19): 4321-4325 (doi: 10.1093/nar/8.19.4321).

16. H u y e $\mathrm{n}$ L.T.N., C u c L.M., I s m a i 1 A.M., H a m L.H. Introgression the salinity tolerance QTLs Saltol into AS996, the elite rice variety of Vietnam. American Journal of Plant Sciences, 2012, 3: 981-987.

17. A m i rova S. Tezisy dokladov IV Vsesoyuznogo simpoziuma «Fiziologicheskie $i$ biokhimicheskie osnovy soleustoichivosti rastenii» [Proc. IV All-Union Symp. «Physiological and biochemical fundamentals of salt tolerance in pants»]. Tashkent, 1986: 76 (in Russ.).

18. Strog a nov B.P. Fiziologicheskie osnovy soleustoichivosti rastenii [Physiological bases of salt tolerance in plants]. Moscow, 1962 (in Russ.).

19. L e o n o v a I.N. Vavilovskii zhurnal genetiki i selektsii, 2013, 17(2): 314-325 (in Russ.).

20. Gregorio G.B., S en adhira D., Me ndoza R.D., Manigbas N.L., Roxas J.P., $\mathrm{Gu}$ e rt a C.Q. Progress in breeding for salinity tolerance and associated abiotic stresses in rice. Field Crops Res., 2002, 76: 91-101 (doi: 10.1016/S0378-4290(02)00031-X).

21. Yamaguchi Y., B lumwald E. Developing salt-tolerant crop plants: challenges and opportunities. Trends Plant Sci., 2005, 10: 615-620 (doi: 10.1016/j.tplants.2005.10.002).

22. I s mail A.M., H e u e r S., Thomson M.J., Wissuwa M. Genetic and genomic approaches to develop rice germplasm for problem soils. Plant Mol. Biol., 2007, 65: 547-570 (doi: 10.1007/s11103-007-9215-2).

23. $\mathrm{Hu}$ S., T a o H., Q i a n Q., Guo L. Genetic and molecular breeding for salt-tolerance in rice. Rice Genomics and Genetics, 2012, 3(7): 39-49 (doi: 10.5376/rgg.2012.03.0007).

24. B l u m w a ld E., G rove r A. Salt tolerance. In: Plant biotechnology: current and future uses of genetically modified crops. N.G. Halford (ed.). UK, John Wiley \& Sons, Ltd, 2006: 206-224 (doi: 10.1002/0470021837.ch11). 
25. Li nh L.H., Li nh T.H, Xuan T.D., Ham L.H., I smail A.M., Kha $\mathrm{nh}$ T.D. Molecular breeding to improve salt tolerance of rice (Oryza sativa L.) in the Red River Delta of Vietnam. International Journal of Plant Genomics, 2012: Article ID 949038 (doi: 10.1155/2012/949038).

26. Wa zi ri A., Ku ma r P., Purty R.S. Saltol QTL and their role in salinity tolerance in rice. Austin J. Biotechnol. Bioeng., 2016, 3(3): 1067.

27. I s 1 a m M.R., S a la $\mathrm{m}$ M.A., $\mathrm{H}$ a s s a $\mathrm{n}$ L. QTL mapping for salinity tolerance at seedling stage in rice. J. Agric. Food Technol., 2011, 23: 137-146.

28. Sabouri H., Rezai A.M., Moumeni A. QTLs mapping of physiological traits related to salt tolerance in young rice seedlings. Biologia Plantarum, 2009, 53: 657-662 (doi: 10.1007/s10535-009-0119-7).

29. Hien Thi Thu Vu, Duc Duy Le, Abdelbagi M. Ismail, Ham Huy Le. Marker-assisted backcrossing (MABC) for improved salinity tolerance in rice (Oryza sativa $\mathrm{L}$.) to cope with climate change in Vietnam. Australian Journal of Crop Science, 2012, 6(12): 1649-1654.

30. Thomson M.J., de Ocampo M., Egdane J., Rahman M.A., Sajise A.G., Adorada D.L., Tumi mbang-Raiz E., B lu mwald E., Seraj Z.I., Singh R.K., Gregorio G.B., I s ma i 1 A.M. Characterizing the Saltol quantitative trait locus for salinity tolerance in rice. Rice, 2010, 3: 148-160 (doi: 10.1007/s12284-010-9053-8). 